PressAcademia Procedia

YEAR 2021 VOLUME 14

Istanbul Finance Congress, November 4-5, 2021

\title{
EXAMINATION OF FINANCIAL CRISES UNDER THE EFFECT OF FINANCIAL CONTAGION: IMPLEMENTATION ON FRAGILE FIVE COUNTRIES
}

\author{
DOI: 10.17261/Pressacademia.2021.1532 \\ PAP- V.14-2021(54)-p.178-179
}

Ali Ihsan Kayaalp ${ }^{1}$, Serkan Cankaya ${ }^{2}$

${ }^{1}$ Istanbul Commerce University, Graduate School of Finance, Department of Banking, Istanbul, Turkey. aihsan.kayaalp@istanbulticaret.edu.tr, ORCID: 0000-0002-3798-6294

2Istanbul Commerce University, Faculty of Business, Department of Banking and Finance, Istanbul, Turkey. scankaya@ticaret.edu.tr, ORCID: 0000-0003-3010-0697

\section{To cite this document}

Kayaalp, A.I., Cankaya, S., (2021). Examination of financial crises under the effect of financial contagion: implementation on fragile five countries. PressAcademia Procedia (PAP), 14, 178-179.

Permanent link to this document: http://doi.org/10.17261/Pressacademia.2021.1532

Copyright: Published by PressAcademia and limited licensed re-use rights only.

\begin{abstract}
Purpose- It is ensured that the markets work in a fair, effective and transparent manner in order to protect the investors in money and capital markets. It is aimed to examine the financial contagion effect, which is of interest to investors trading in these markets, in Brazil, Indonesia, India, Turkey and South Africa, which are stated as having high current account deficit, high inflation rate, unstable growth and increasing external financing needs in the report prepared by Morgan Stanley in 2013.

Methodology- The contagion effect of the financial markets of the developed countries to the financial markets of the developing countries was analyzed econometrically with the help of the $\mathrm{MSCl}$ (Morgan Stanley Capital International) index and the interest rates of the related countries with the help of the E-views (v.9) statistical package program.

Findings- As a result of granger causality analysis in econometric models designed by including the financial crisis conditions, the presence of contagion effect in the financial markets of developed and developing countries, $\mathrm{MSCl}$ Indices of Fragile Five Countries (Brazil, Indonesia, India, South Africa and Turkey), USA Interest Rate Granger cause stands out. . According to this result, it shows the effect of developed countries on the financial markets of developing countries.

Conclusion- The findings of the research contain important information in explaining the contagiousness of the crises in the financial markets. Using this information, it is expected to direct new research and enable investors to make the right decisions.

Keywords: Financial crisis, financial contagion, the fragile five

JEL Codes: C01, G01,F40

\section{FINANSAL KRIZLERIN FINANSAL BULAŞMA ETKISI ALTINDA INCELENMESI: KIRILGAN BEŞLI ÜLKELER ÜZERINE UYGULAMA}

\section{ÖZET}

Amaç-Para ve sermaye piyasalarında yatırımcının korunması için piyasaların adil,etkin ve şeffaf bir şekilde çalışması sağlanmaktadır. Bu piyasalarda işlem yapan yatırımcılar ilgilendiren finansal bulaşma (financial contagion) etkisinin, 2013 yılında Morgan Stanley tarafından hazırlanan raporda yüksek cari açıklık, yüksek enflasyon oranı, istikrarsız büyüme ve artan dış finansman ihtiyacına sahip olarak belirtilen Brezilya, Endonezya, Hindistan, Türkiye ve Güney Afrika (Kırılgan Beşli) ülkelerinde incelenmesi amaçlanmaktadır.

Yöntem- Gelişmiş ülkelere ait finansal piyasaların gelişmekte olan ülkelerin finansal piyasalarına olan bulaşma etkisinin MSCI (Morgan Stanley Capital International) endeksi ve ilgili ülkelerin faiz oranları E-views (v.9) istatistik paket programı yardımıyla ekonometrik olarak analiz edilmiştir.

Bulgular- Gelişmiş ülkeler ve gelişmekte olan ülkelerin finansal piyasalarında bulaşma etkisinin varlığı finansal kriz koşulları dahil edilerek tasarlanan ekonometrik modellerde granger nedensellik analizi sonucunda Kırılgan Beşli Ülkelerinin (Brezilya, Endonezya, Hindistan, G.Afrika ve Türkiye) $\mathrm{MSCl}$ Endeksleri, ABD Faiz Oranı Granger nedeni olduğu öne çıkmaktadır. Bu sonuca göre gelişmiş ülkelerin gelişmekte olan ülkelerin finansal piyasaları üzerine etkisini göstermektedir.

Sonuç- Yapılan araştırmada bulunan bulgular finansal piyasalardaki yaşanan krizlerin bulaşıcılığını açıklamada önemli bilgiler içermektedir. Bu bilgileri kullanarak yeni araştırmalara yön vermesini ve yatırımcıların doğru kararlar almasını sağlaması beklenmektedir.

Anahtar Kelimeler: Finansal kriz, finansal bulaşma, kırılgan beşli

JEL Kodları: C01, G01, F40 


\section{REFERENCES}

Ahlgren, N., \& Antell, J. (2010). Stock Market Linkages and Financial Contagion: A Cobreaking Analysis. The Quarterly Review of Economics and Finance, 50, 157-166.

Baig, T., \& Goldfajn, I. (1999). Financial Market Contagion in The Asian Crisis. IMF Staff Papers, 46(2), 167-195.

Boztosun, D., \& Çelik, T. (2011). Türkiye Borsasının Avrupa Borsaları ile Eşbütünleşme Analizi. Süleyman Demirel Üniversitesi İktisadi ve İdari Bilimler Fakültesi Dergisi, 16, 147-162.

Corsetti, G., Pericoli, M., \& Sbracia, M. (2005). Some Contagion, Some Interdependence: More Pitfalls in Tests of Financial Contagion. Journal of International Money and Finance, 24, 1177-1199.

Dasgupta, R. (2013). BRIC and US Integration and Dynamic Linkages an Empirical Study for International Diversification Strategy. Interdisciplinary Journal of Contemporary Research in Business, 5(7), 536-563

Dickey, D. A., \& Fuller, W. A. (1979). Distribution of the Estimators for Autoregressive Time Series with a Unit Root. Journal of the American Statistical Association, 74(366a).427-431.

Dornbusch, R., Park,Y. C.,\& Claessens S. (2000). Contagion: Understanding How It Spreads. The WorldBank Research Observer, 15(2), 177 197

Eichengreeen, B., Rose, A., \& Wyplosz, C. (1996). Contagious Currency Crisis:First Tests. The Scandinavian Journal of Economics, 98(4), 463484.

Erkekoğlu, H.,\& Bilgili, E. (2005). Parasal Krizlerin Tahmin Edilmesi: Teori ve Uygulama. Erciyes Üniversitesi İktisadi ve İdari Bilimler Fakültesi Dergisi, 24, 5-36.

Forbes, K. J.,\& Rigobon, R. (2002). No Contagion, Only Interdependence: Measuring Stock Market Co-movements. Journal of Finance, 575, 2223-2261.

Kenourgios, D., Christopoulos A. \& Dimitriou, D. (2013). Asset Markets Contagion During the Global Financial Crisis. Multinational Finance Journal, 17, 49-76.

King, M.A., \& Wadhwani, S. (1990). Transmission of Volatility Between Stock Markets The Review of Financial Studies, 3(1), 5-33.

Oktar, S., \& Dalyancı, L. (2010). Finansal Kriz Teorileri ve Türkiye Ekonomisinde 1990 Sonrası Finansal Krizler. Marmara Üniversitesi i.I.B.F. Dergisi, 24(2).1-22.

Şahin, C.,\& Sümer, K. K., (2014). Gelişmiş ve Gelişmekte Olan Ülke Borsaları ile Türk Borsası Arasındaki Etkileşime Yönelik Bir İnceleme. Trakya Üniversitesi Sosyal Bilimler Dergisi, 16(2), 315-338.

Samarakoon, L.P., (2011). Stock Market Interdependence, Contagion, and The U.S. Financial Crisis: The Case of Emerging and Frontier Markets. Journal of International Financial Markets, Institutions \& Money, 21, 724-742. 